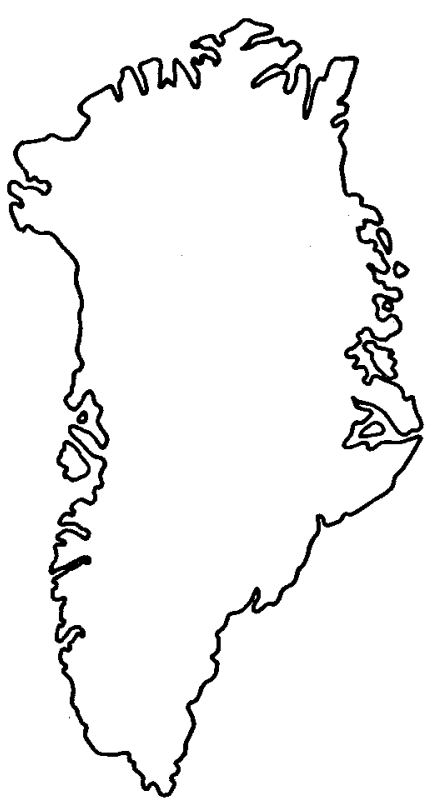

\title{
Trace fossils from Silurian slope deposits, North Greenland
}

\author{
Ron K. Pickerill and Tom L. Harland
}

Nine ichnospecies are recorded from the lower part of the Wulff Land Formation (Early Wenlock) on the east side of the valley north of Apollo Sø in Wulff Land, western North Greenland. There, the formation consists of a siliciclastic slope sequence of dark grey mudstones interbedded with subordinate siltstones and sandstones. The trace fossils are: cf. Chondrites ichnosp., Gordia marina, Helminthopsis ichnosp., Megagrapton irregulare, Muensteria ichnosp., Neonereites multiserialis ichnosp. nov., Nereites jacksoni, Paleodictyon (Glenodictyon) imperfectum and Paleodictyon ichnosp. In addition to containing a new ichnospecies, the assemblage documents only the second detailed account of trace fossils in Lower Palaeozoic slope sequences; most of the ichnospecies have not been recorded previously in such sequences.

R. K. P., Department of Geology, University of New Brunswick, P.O. Box 4400, Fredericton, New Brunswick, Canada E3B 5 A3.

T. L. H., Poroperm-Geochem Limited, Chester Street, Saltney, Chester CH4 8RD, U.K.

Unlike basinal flysch and shallow water clastic and carbonate deposits, slope deposits have very imperfectly known trace fossil assemblages. This is particularly true of Lower Palaeozoic sediments, where most ichnological studies have dealt with shelf clastics (see, for example, Fillion \& Pickerill, in press). Trace fossils from Lower Palaeozoic shelf carbonates (e.g. Narbonne, 1984; Pickerill et al., 1984) and basinal deposits (e.g. Pickerill, 1980, 1981; Benton, 1982) are more rarely documented, whereas traces from Lower Palaeozoic slope deposits remain virtually unknown. To our knowledge, the only trace fossils described in detail from such a sequence are those from Arctic Canada (Narbonne, 1984) which occur in a similar sequence to that in North Greenland. The trace fossils documented here, which were collected during a rapid preliminary reconnaisance of the area, are thus important on two accounts: first as records, per se, of the types of traces to be found in Lower Palaeozoic slope deposits and, secondly, their documentation offsets the imbalance of trace fossil descriptions in the existing literature (for review see Ekdale et al., 1984). 


\section{Geological Setting}

The Lower Palaeozoic of North Greenland comprises extensive outcrops of southerly platform and northerly deep-water sediments (fig. 1) which represent the eastward continuation of the Franklinian Basin of adjacent Ellesmere Island, Canada (Trettin, 1971; Kerr, 1976; Peel, 1982). During the Silurian, the platform margin was generally defined by a variety of carbonate mound complexes, many of which continued to accrete whilst the northern part of the platform was progressively drowned by fairly continuous subsidence (Sønderholm et al., 1987). On or at the edge of the platform itself, an up to $2 \mathrm{~km}$ thickness of shallow water platform carbonates accumulated and to the north a mainly deep-water clastic sequence at least $6 \mathrm{~km}$ thick infilled the trough. During the Silurian, the platform to trough transition was generally very rapid and it was undoubtedly steep and complicated by the presence of the platform-edge mounds (fig. 2). Slope deposits comprise a complex interdigitation of starved toe-of-slope mudstones, thick conglomerates comprising large blocks of limestone derived from the platform and the mounds, down-slope carbonate build-ups and packets of interbedded mudstones, siltstones and thin sandstones (fig. 2).
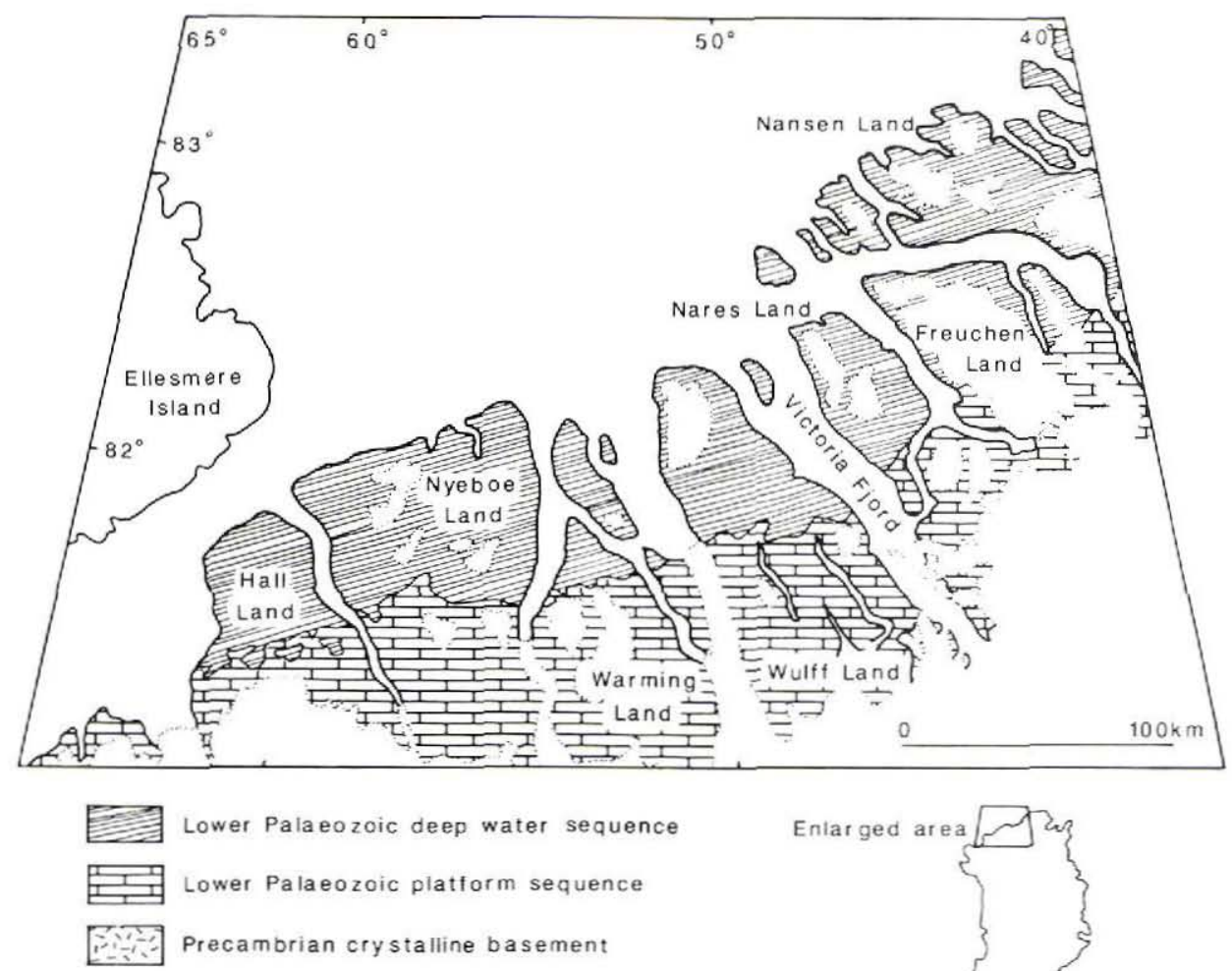

Limits of ice caps/glaciers

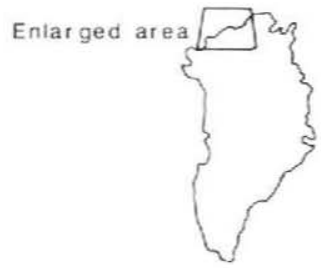

Fig. 1. Simplified geological map of central and western North Greenland showing southerly platform and northerly basin sediments. 

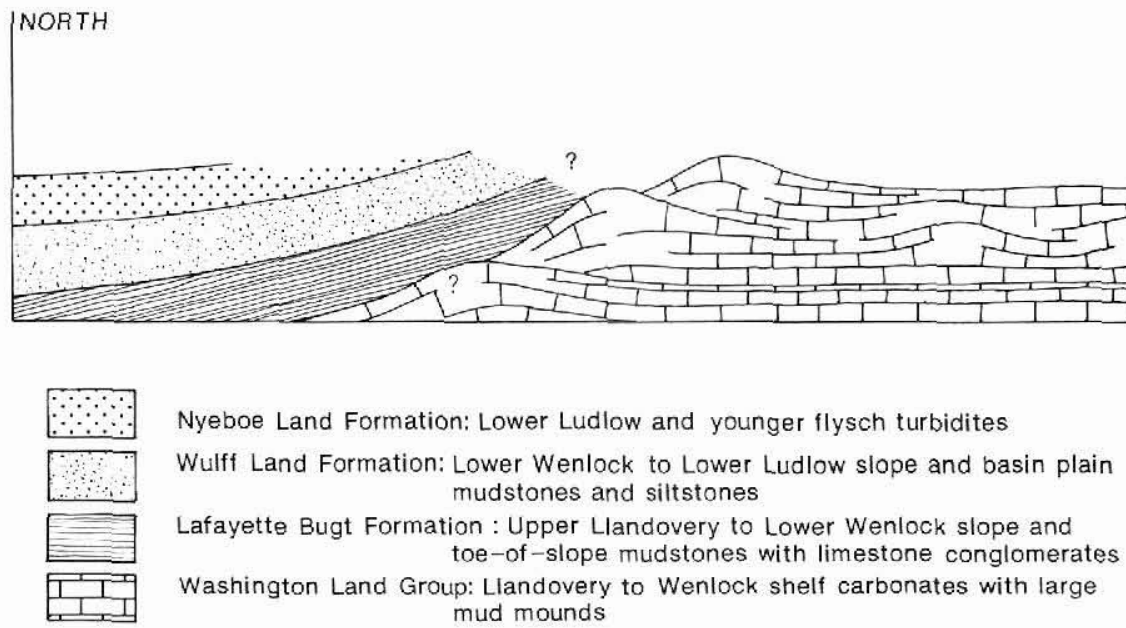

Fig. 2. Schematic profile of the Silurian sequence north of Apollo Sø in Wulff Land showing southerly platform carbonates with platform and platform-edge mounds and flanking slope deposits to the north (cf. fig. 3a).

The trace fossils described herein were collected from silty/sandy horizons in the lower part of the Wulff Land Formation (probably Early Wenlock) on the east side of the valley north of Apollo Sø in Wulff Land (figs 2, 3). The Wulff Land Formation comprises dark grey siliciclastic mudstones interbedded with subordinate thin beds of siltstones and fine-grained sandstones, which have been interpreted as slope and basin plain deposits (Hurst \& Surlyk, 1982). There is no evidence that sediments of the formation overlapped onto the southerly carbonate platform, although this seems likely. To the north, sediments of the Wulff Land Formation interdigitate with and are overlain by turbidites of the Lauge Koch Land Formation (Hurst \& Surlyk, 1982). Thus, although the Wulff Land Formation extends northwards, the samples described here are from the most proximal areas to the platform where steeper than general dips and intercalated slumped horizons are suggestive of deposition on a substantial slope.

\section{Trace fossil descriptions}

In accordance with common ichnological procedure (Häntzschel, 1975) the trace fossils from the twelve available slabs (GGU collections 301515-301526 inclusive) are described below in alphabetical order rather than in any morphological or behavioural groupings. Detailed discussions regarding the producer(s) of individual trace fossils, and their environmental and stratigraphic occurrence are omitted; such discussions can be obtained in a variety of recent publications (e.g. Crimes \& Harper, 1977; Häntzschel, 1975; Ksiazkiewicz, 1977; Ekdale et al., 1984). 

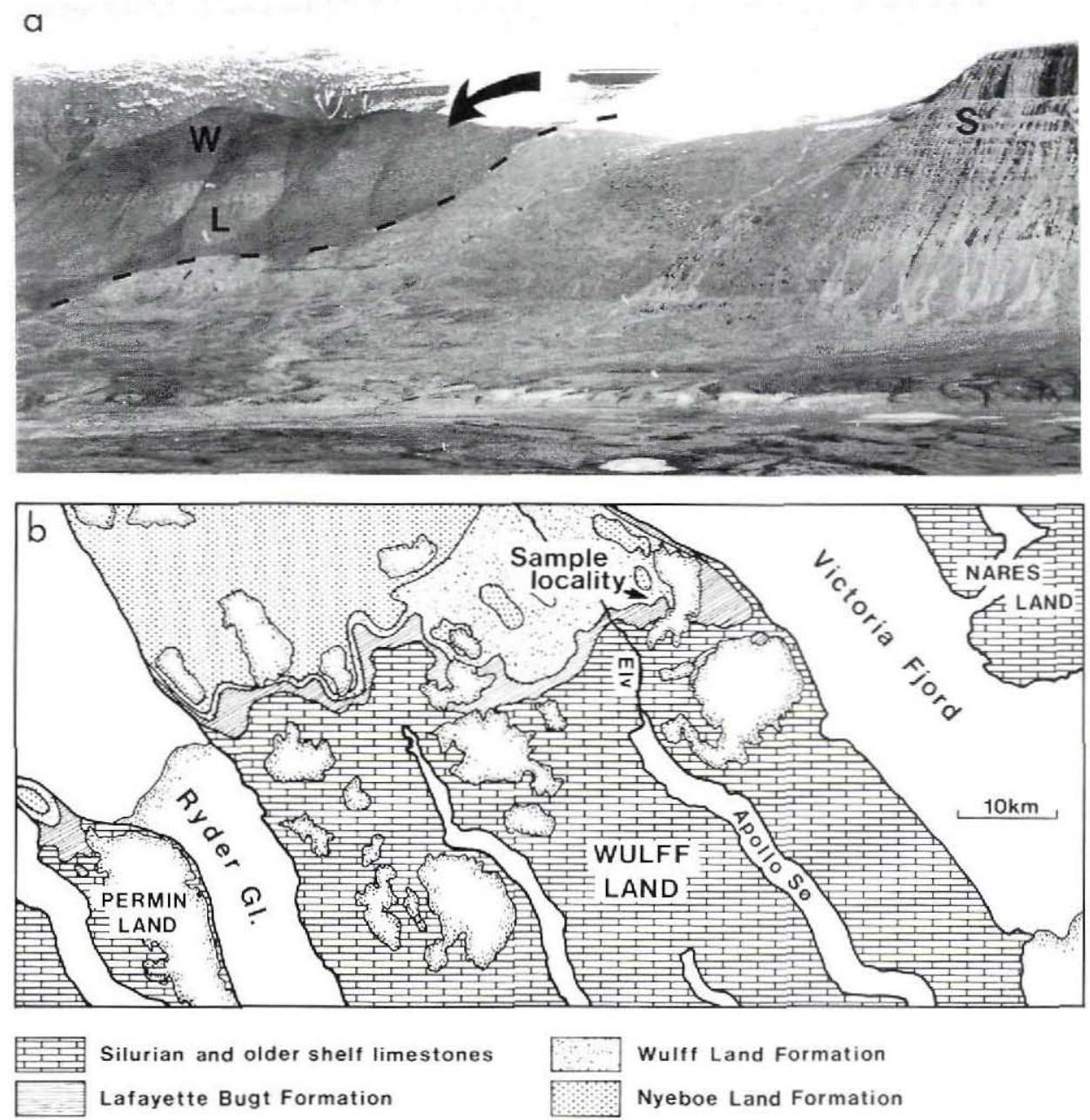

Fig. 3. Sample locality (arrowed): a. Field photograph of the valley side north of Apollo Sø, which shows the margin of the Silurian carbonate shelf (S) flanked to north by slope deposits of the Lafayette Bugt (L) and Wulff Land (W) Formations. b. Geological sketch map of the central Wulff Land area.

Ichnogenus Chondrites von Sternberg, 1883 cf. Chondrites ichnosp.

Fig. 4a

Description. A single specimen (MGUH 18.290 from GGU collection 301517) preserved in positive hyporelief on a fine-grained sandstone sole. The trace forms a dendritic network of burrows which extend distally for at least $8 \mathrm{~cm}$ from a poorly-preserved apex. Individual burrows are $4 \mathrm{~mm}$ in diameter; burrow fill is of identical grain size to enclosing sediment. A 

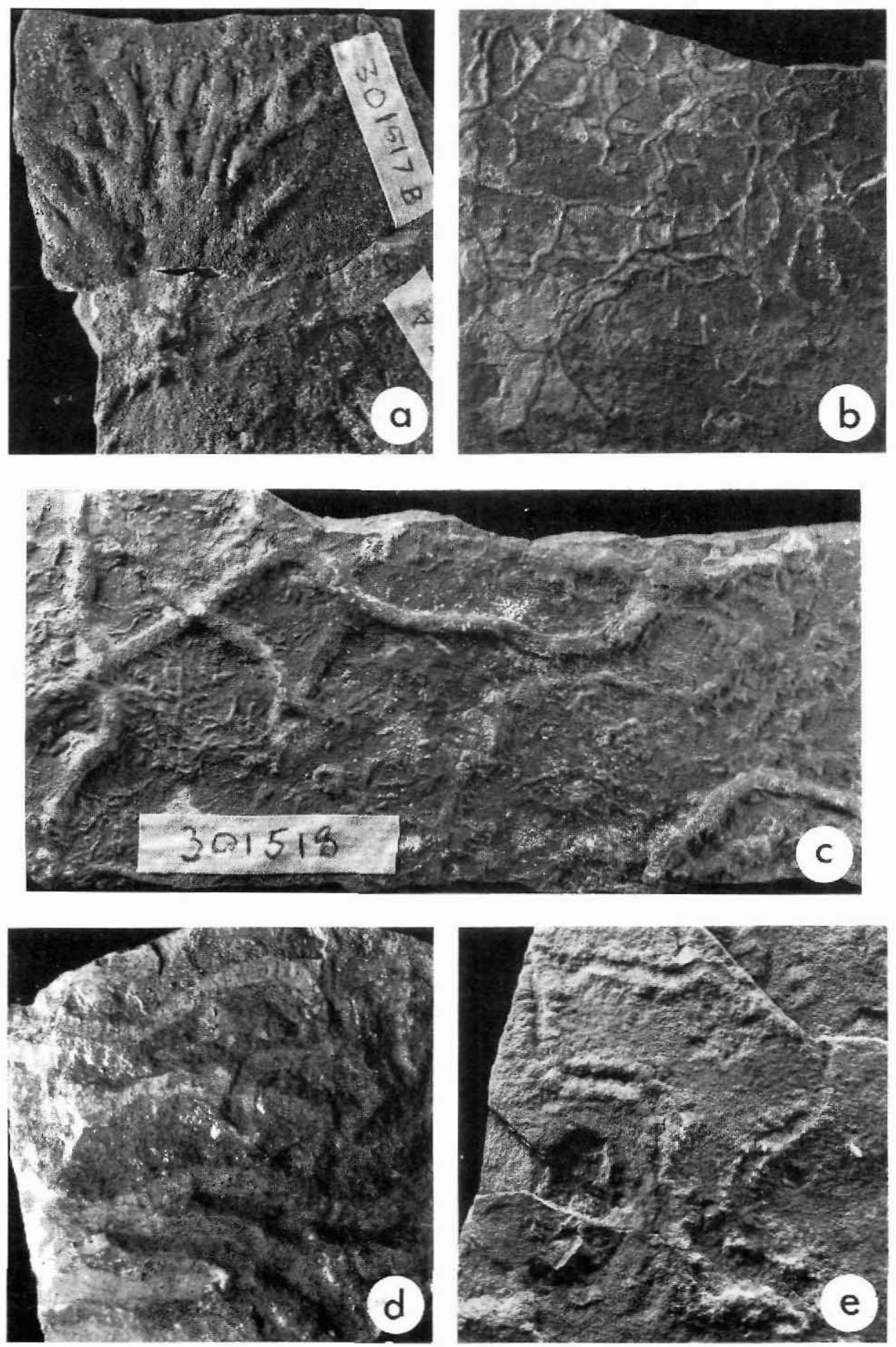

Fig. 4. a. cf. Chondrites ichnosp., $\times$ 0.6. MGUH 18.290 from GGU collection 301517. b. Gordia marina Emmons, 1844, × 0.8. MGUH 18.291 from GGU collection 301519. c. Helminthopsis ichnosp., $\times 0.67$. MGUH 18.292 from GGU collection 301518. d. Muensteria ichnosp., $\times$ 0.8. MGUH 18.293 from GGU collection 301522. e. Nereites jacksoni Emmons, 1844, × 0.75. MGUH 18.294 from GGU collection 301515 . 
single order of branching at relatively acute angles $\left(30-35^{\circ}\right)$ is present, though not throughout; no swellings occur at the branches.

Remarks. The specimen is only tentatively identified as Chondrites von Sternberg, 1883 because it lacks the truly dendritic and ramifying branching systems characteristic of this ichnogenus. Additionally, the individual burrows are rather large in diameter compared to most previously described examples. The specimen somewhat resembles Phycodes Richter, 1850 in plan view (see Fillion \& Pickerill, in press) but cannot be assigned to this ichnogenus because of the absence of a Spreite. Chondrites is a facies-crossing trace produced by a variety of organisms (see Fillion \& Pickerill, 1984) and ranges in age from Late Precambrian to Holocene (Häntzschel, 1975; Ekdale, 1977; Crimes \& Germs, 1982).

\section{Ichnogenus Gordia Emmons, 1844 Gordia marina Emmons, 1844}

Fig. 4b

Description. A single specimen (MGUH 18.291 from GGU collection 301519) forming a dense network, and isolated and incomplete burrow segments in GGU collection 301515 in association with Nereites jacksoni Emmons, 1844, comprise curved, meandrine burrows that exhibit no systematic meander patterns, burrows $0.9 \mathrm{~mm}$ in diameter (which appears constant but is difficult to determine precisely) and showing a tendency to level crossing. Burrows are smooth, horizontal, unbranched and possess an identical fill to that of the enclosing sediment.

Remarks. The original scanty description of the ichnogenus has led to confusion and taxonomic inconsistencies but most authors regard the presence of level crossing as diagnostic (see Fillion \& Pickerill, in press). The other common ichnospecies, G. molassica Heer, 1865 should be regarded as a junior synonym of $G$. marina (Pickerill, 1981). Gordia is a facies-crossing trace ranging in age from Late Precambrian to Holocene (Häntzschel, 1975).

\section{Ichnogenus Helminthopsis Heer, 1877 \\ Helminthopsis ichnosp.}

Fig. $4 \mathrm{c}$

Description. Irregularly winding or meandering smooth burrows of variable length preserved in convex hyporelief on fine-grained sandstone soles. Individual burrows do not touch or cross themselves but separate systems may intersect. Burrows range in diameter from 2.5-5 $\mathrm{mm}$; burrow diameter is constant in individual specimens. Burrow fill is identical or, rarely, coarser grained than enclosing sediment.

Remarks. Detailed discussions of various aspects of Helminthopsis Heer, 1877, including its various ichnospecies and environmental and stratigraphic distributions, have been presented by Ksiazkiewicz (1977) and more recently by Fillion \& Pickerill (in press), who show that the ichnogenus is a facies-crossing form ranging in age from Late Precambrian to Holocene. The 
trace is the most commonly occurring form in the available collections; it is only identified at the ichnogeneric level because the small size of the available slabs precludes a more rigorous analysis of the exact courses followed by most specimens, which is a prerequisite for ichnospecies determination (Ksiazkiewicz, 1977).

\section{Ichnogenus Megagrapton Ksiazkiewicz, 1968 Megagrapton irregulare Ksiazkiewicz, 1968}

Fig. 6a

Description. A single specimen (MGUH 18.297 from GGU collection 301521) preserved in positive hyporelief on a fine-grained sandstone sole; consists of widely spaced (up to 32 $\mathrm{mm}$ ), irregular and incomplete polygonal networks of relatively large diameter (2-3 mm) burrows. Burrow segments are variable in length $(5-15 \mathrm{~mm})$, are straight to gently curved, and are smooth. Branching is irregular but typically at high angles of $70-90^{\circ}$.

Remarks. Detailed systematic studies of Megagrapton Ksiazkiewicz, 1968 have been presented by both Seilacher (1977) and Ksiazkiewicz (1977), though M. irregulare Ksiazkiewicz, 1968 is the only ichnospecies they recognise in common. $M$. irregulare is characterised by its irregular and incomplete polygonal networks and relatively large burrow diameter. To date it has been recorded only rarely from Lower Palaeozoic (Ordovician) strata (Chamberlain, 1977) and is more typically a deep-water Mesozoic ichnospecies (Ksiazkiewicz, 1977).

\section{Ichnogenus Muensteria von Sternberg, 1833 \\ Muensteria ichnosp.}

Fig. 4d

Description. Ten individual burrows preserved on a single slab (MGUH 18.293 from GGU collection 301522), all approximately $5 \mathrm{~mm}$ in diameter and with diameter constant along exposed length. Burrows are parallel to stratification; specimen is not orientated and it is unknown whether burrows are on top or lower surface. Individual burrows are unbranched, curved to irregularly meandrine, sharp walled; intersections are rare. They possess sharply defined unlined walls and a finer grained but variably preserved greenish clay infill. Where better preserved, the internal fill possesses gently curved meniscae, up to ten per centimetre and essentially perpendicular to the burrow walls.

Remarks. Muensteria von Sternberg, 1833 is a poorly-defined ichnogenus (Häntzschel, 1975) and its relationship to other simple meniscate burrows such as Hydrancyclus von FischerDoster, 1858, Keckia Glocker, 1841 and Scalarituba Weller, 1899 is very vague. Clearly, taxonomic re-evaluation of meniscate burrows is necessary as most are probably synonyms. This revision is being undertaken currently, as noted by Squires \& Advocate (1984); until this detailed evaluation is published, Muensteria is regarded as the most suitable descriptor for simple meniscate burrows by law of priority. Simple meniscate burrows range throughout the Phanerozoic and are facies-crossing forms. 


\section{Ichnogenus Neonereites Seilacher, 1960 \\ Neonereites multiserialis ichnosp. nov. \\ Fig. 5a, b}

Holotype. MGUH 18.295 from GGU Sample 301523.

Paratype. MGUH 18.296 from GGU Sample 301520.

Horizon and location. Wulff Land Formation (Silurian, Early Wenlock), east side of the valley north of Apollo Sø in Wulff Land (fig. 3).

Diagnosis. Neonereites Seilacher, 1960 with chains composed of more than two rows of pustules or pods. when preserved in convex hyporelief or, conversely, dimples or pods in epirelief.

Description. The holotype is preserved in convex hyporelief on the sole of a $25 \mathrm{~mm}$ thick, parallel laminated to low angle cross-laminated fine-grained sandstone. It consists of a meadering 'trail', $25 \mathrm{~cm}$ in total length (though incompletely preserved along $9 \mathrm{~cm}$ ) and with an average width of $2.3 \mathrm{~cm}$. The trail has a reasonably well-defined axial medial groove on either side of which are arranged juxtaposed compound biserial pods. Though preservation is sometimes incomplete, the 'trail' therefore possesses quadriserial pods across its width, though occasionally they are triserial. Individual pods are circular or subcircular, smooth, but exhibit an irregular surface; they vary in diameter from $0.4-0.8 \mathrm{~mm}$. Projecting from close to one extremity of the holotype is a prong of essentially biserial pods with no well-defined medial groove. The holotype slab also preserves a small isolate poorly-preserved trace which is akin to $N$. multiserialis. The paratype is $5.5 \mathrm{~cm}$ in length with a maximum width of $2 \mathrm{~cm}$. Similarly preserved in convex hyporelief, the trail consists of triserial and, mainly, quadriserial, smoothly circular or subcircular pods, $0.4-0.5 \mathrm{~mm}$ in diameter, with only a weakly defined medial groove.

Remarks. Neonereites was erected by Seilacher (1960) for irregularly curving chains of uniserially or biserially arranged dimples when preserved as negative epireliefs, or pods or pustules when preserved as positive hyporeliefs. Benton (1982) has subsequently reported the ichnogenus preserved as positive epireliefs (hence demonstrating that they are truly spheroidal) but we are unaware of any records of preservation in concave hyporelief. Our diagnosis of the new ichnospecies therefore allows for preservation in both concave and convex epirelief but only for convex hyporelief.

Seilacher \& Meischner (1965) and Chamberlain (1971) suggested that Neonereites was probably a behavioural variant of the ichnogenera Scalarituba Weller, 1899 and Nereites MacLeay, 1839 (= Phyllodocites Geinitz, 1867 view), but they did not formally enforce the synonymy. Additionally, many authors still prefer to regard these ichnogenera as distinctive, particularly when dealing with more poorly preserved material than that available to Seilacher \& Meischner (see, for example, Pickerill, 1981; Benton, 1982; Crimes \& Germs, 1982; Turner \& Benton, 1983).

Until now, Neonereites possessed two ichnospecies, $N$. uniserialis Seilacher, 1960 and $N$. biserialis Seilacher, 1960, which are characterised respectively by uniserial and biserial rows 

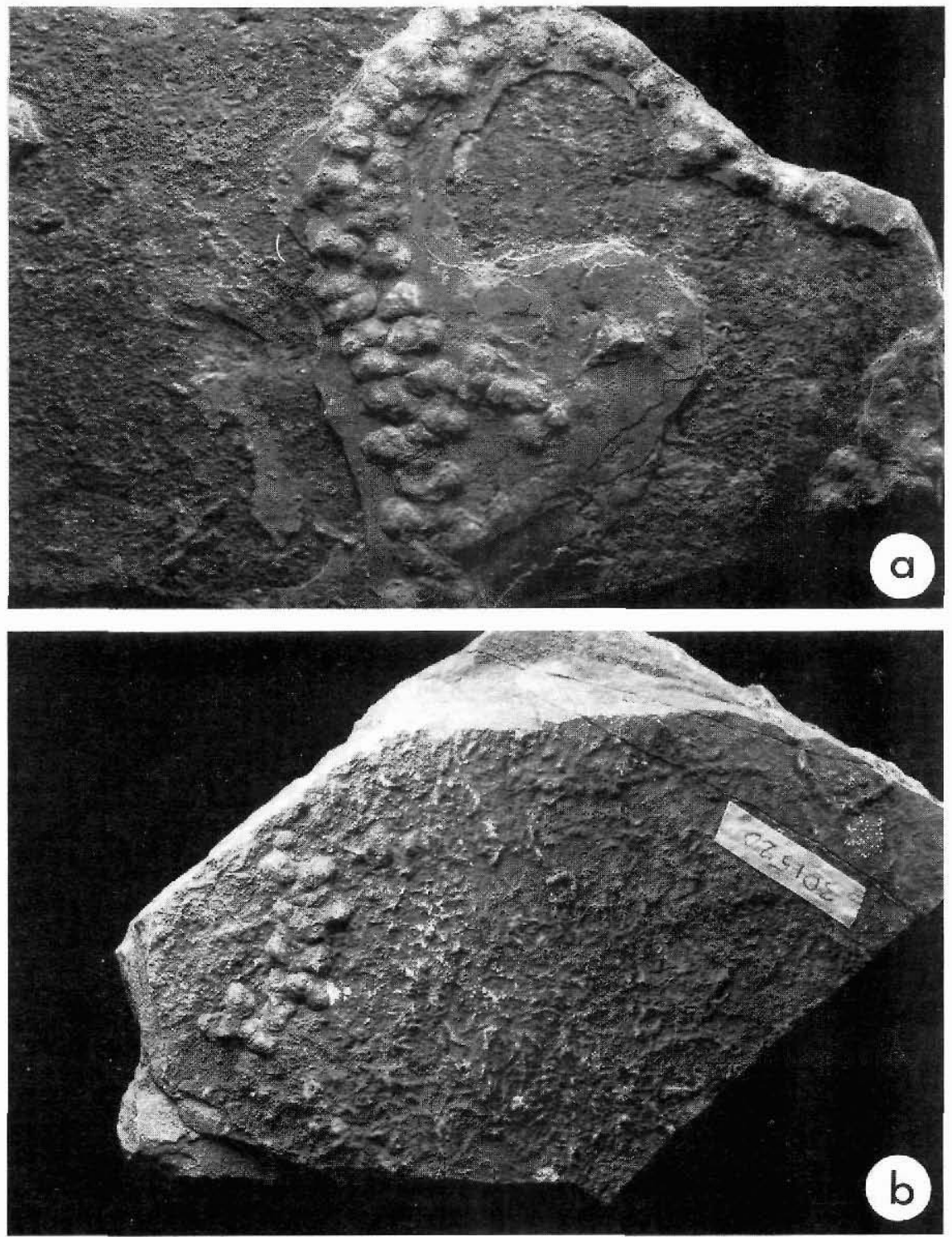

Fig. 5. a. Holotype of Neonereites multiserialis ichnosp. nov., $\times 0.5$. MGUH 18.295 from GGU collection 301523. b. Paratype of Neonereites multiserialis ichnosp. nov., $\times 0.45$. MGUH 18.296 from GGU collection 301520 .

of pustules or pods. The Greenland material cannot be accommodated at the ichnospecific level into either $N$. uniserialis or $N$. biserialis. Ekdale et al. (1984, fig. 18-5, p. 239) have figured a smaller example identified merely as Neonereites but which is probably conspecific with $N$. multiserialis. 
Neonereites Seilacher, 1960 is a facies-crossing form ranging in age from Late Precambrian (Fedonkin, 1977) to Tertiary (Häntzschel, 1975).

\section{Ichnogenus Nereites MacLeay, 1839 \\ Nereites jacksoni Emmons, 1844}

Fig. $4 \mathrm{e}$

Description. Several specimens preserved in GGU collection 301515 in negative epirelief. Individual traces are generally poorly preserved and consist of variably and irregularly sinuous to meandering burrows, each $2 \mathrm{~mm}$ in diameter and of consistent width along exposed courses. In places, individual burrows possess a green clay fill; where clay fill is absent, burrow fill is identical to enclosing fine-grained sandstone. Though typically structureless, the burrow fills rarely show crude meniscate-like structures developed perpendicular to the burrow walls. Notably, however, these are developed only in those portions of individual burrows orientated normal to the well-developed fracture pattern in the slab. On each side of individual burrows are poorly-preserved dense $(3-4$ per $\mathrm{cm})$, rounded and smooth lobes up to $2.5-3 \mathrm{~mm}$ in length.

Remarks. The detailed systematic ichnology of Nereites MacLeay, 1839 has been recently undertaken by Benton (1982). Of the four ichnospecies he recognised, the Greenland material is most closely comparable to $N$. jacksoni Emmons, 1844 and is diagnosed as such. This has also been confirmed by comparison with topotype material from the Silurian Waterville Formation of Maine (R. K. Pickerill, personal observations). Although forming the type ichnogenus of the deep-water marine Nereites ichnofacies of Seilacher (1967), Nereites has been reported from a wide variety of marine settings and should be regarded as facies-crossing (Hakes, 1976). It ranges in age from the Vendian/Tommotian (Crimes \& Germs, 1982) to Holocene (Gregory, 1969).

Ichnogenus Paleodictyon Menegheni, 1850

Paleodictyon (Glenodictyon) imperfectum Seilacher, 1977

Fig. 6b

Description. A single specimen (MGUH 18.298 from GGU collection 301525) preserved in positive hyporelief on a fine-grained sandstone sole. It consists of a polygonal burrow network typified by unequally sized and shaped polygons. Individual polygons may be complete or incomplete; where the former they are typically hexagonal. Polygons are 8-13 $\mathrm{mm}$ across and the burrows are $1.0-1.5 \mathrm{~mm}$ in diameter and virtually circular in crosssection. The burrows run in straight to gently curved lines for $4-8 \mathrm{~mm}$ before turning at angles of $10-80^{\circ}$.

Remarks. Although detailed systematic treatments of Paleodictyon Menegheni, 1850 have been given by both Seilacher (1977) and Ksiazkiewicz (1977), its ichnospecies and exactly which criteria should be utilised to recognise distinctive ichnospecies remain unresolved. Both these authors recognise many (and different) ichnospecies based on different criteria 

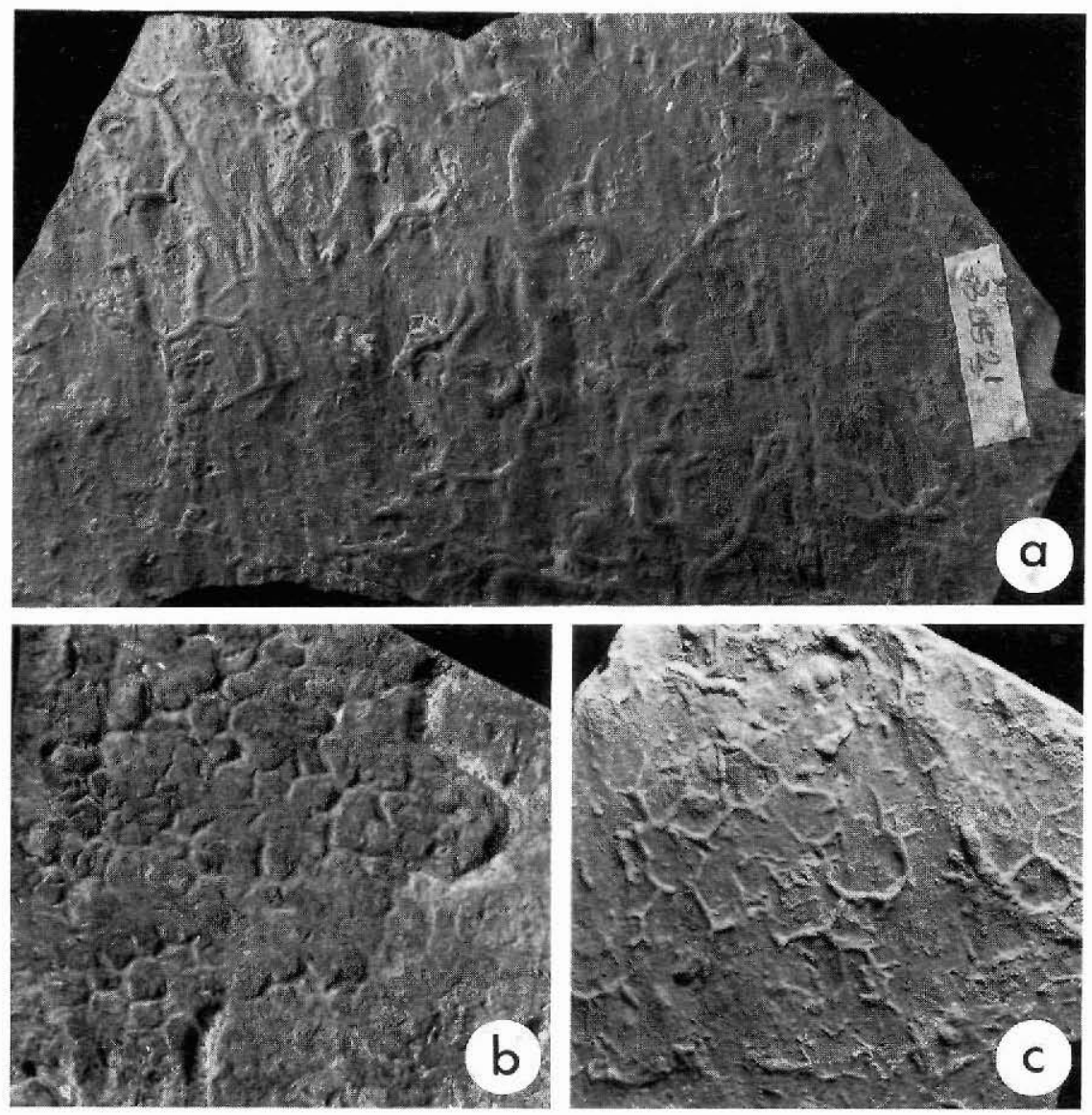

Fig. 6. a. Megagrapton irregulare Ksiazkiewicz, $1968, \times 0.45$. MGUH 18.297 from GGU collection 301521. b. Paleodictyon (Glenodictyon) imperfectum Seilacher, 1977, $\times 0.55$. MGUH 18.298 from GGU collection 301525. c. Paleodictyon ichnosp., $\times$ 0.85. MGUH 18.299 from GGU collection 301516.

and a systematic review of the ichnogenus is still necessary. Nevertheless, the specimen herein is clearly conspecific with $P$. (Glenodictyon) imperfectum as described by Seilacher (1977) and Benton (1982), and it is diagnosed as such. Paleodictyon is essentially Ordovician (Pickerill, 1980) to Holocene (Ekdale, 1980) in age and is typically, though not exclusively, a deep-water trace. The Cambrian recording by Crimes \& Anderson (1985) is questionable, at best.

\section{Paleodictyon ichnosp.}

Fig. 6c

Description. A single specimen (MGUH 18.299 from GGU collection 301516) poorly preserved in positive hyporelief on a fine-grained sandstone sole. It consists of generally incomplete, rarely complete, irregular polygonal nets $6-8 \mathrm{~mm}$ across. Burrows run in 
straight to gently curved lines for $3-7 \mathrm{~mm}$ before turning at angles of $10-90^{\circ}$ and are extremely narrow, typically less than $1 \mathrm{~mm}$ diameter.

Remarks. The poor and incomplete preservation of most nets precludes ichnospecies determination of this specimen. The smaller net size and narrower burrow diameter suggest, however, that the specimen is not $P$. (Glenodictyon) imperfectum as described above.

\section{Discussion}

Submarine slopes, be they modern or ancient, are undoubtedly features that exhibit considerable topographic and physiographic variation, particularly with respect to the inclusion of intraslope basins and, especially, channelised features such as canyons, channels, chutes and gullies with their associated fans (see Cook et al., 1982; Buck \& Bottjer, 1985). Channel and fan sequences in the fossil record are well documented, as are their contained trace fossil assemblages (e.g. Crimes, 1977; Pickerill, 1981; Ekdale et al., 1984). However, 'interchannel' slope deposits (sensu Buck \& Bottjer, 1985) and their trace fossil assemblages remain poorly documented, particularly those of Lower Palaeozoic age.

The Wulff Land Formation is a slope to basin sequence in which channellised or fan facies associations have not been recognised (Hurst \& Surlyk, 1982). Presumably such slope sequences as that represented by the Wulff Land Formation or 'interchannel' slope deposits sensu Buck \& Bottjer (1985) were subject to different physico-chemical conditions than their channelised/fan counterparts. Different trace fossil assemblages may exist, therefore, in such different sequences (Crimes, 1977), though much more data than those presented here are required to test this hypothesis. Indeed, we are aware of only a single example where trace fossils have been described from a comparable Lower Palaeozoic slope sequence to that present in North Greenland (Narbonne, 1984, see below). However, Narbonne \& Packard (1983) recorded the ichnogenera Cruziana d'Orbigny, 1842, Lockeia James, 1879, Phycodes Richter, 1850, Pilichnia Chamberlain, 1971, Taenidium Heer, 1877 and Zoophycos Massalongo, 1855 from Silurian-Devonian slope deposits of Somerset, Griffith, Cornwallis and Devon Islands in Arctic Canada and Narbonne \& James (1984) report Cylindrichnus Toots in Howard, 1966, Diplocraterion?, Palaeophycus Hall, 1847, Planolites Nicholson, 1873, Skolithos Haldemann, 1840 and Syncoprulus Richter \& Richter, 1939 from the Cow Head Group (Cambrian-Ordovician) of western Newfoundland. Unfortunately these preliminafy reports have not been published in detail and the occurrences cannot be realistically assessed.

The material under consideration here contains a total of nine distinctive ichnospecies. Of these, Helminthopsis is the most commonly occurring form and the remainder are represented by single or relatively few specimens. At the ichnogeneric level, it is evident that most traces are facies-crossing forms (e.g. Chondrites, Gordia, Helminthopsis, Muensteria, Neonereites), which have been reported from a variety of neritic to basinal flysch regimes. It is hardly surprising, therefore, that these forms should occur in slope deposits, particularly as they all range throughout the Phanerozoic and some (Helminthopsis, Neonereites) even into the Vendian. Nevertheless, apart from questionable Neonereites reported by Narbonne (1984) from Silurian slope deposits of Arctic Canada (see below), none of the forms have previously been recorded in Lower Palaeozoic slope sequences. This is also true of the remaining ichnogenera (Megagrapton, Nereites, Paleodictyon) which are typically reported 
from basinal flysch sequences and only on occasion from shallow water neritic regimes (Hakes, 1976; Crimes \& Anderson, 1985).

As noted above only a single description of Lower Palaeozoic slope trace fossil assemblages has been published to date. In this, Narbonne (1984) lists the following ichnogenera: Chondrites, ?Neonereites, Margaratichnus?, Palaeophycus, Phycodes, Skolithos and Teichichnus Seilacher, 1955. This assemblage contrasts markedly with that described above from the Wulff Land Formation. Stringer \& Pickerill (1980) have interpreted the Matapedia Group (Middle Ordovician - Lower Silurian) of northern New Brunswick, eastern Canada as another slope deposit (see also Pickerill, 1980) and, although as yet unpublished, the trace fossil assemblage from this sequence comprises Chondrites, Glockerichnus Pickerill, 1982, Gordia, Helminthoida Schafhautl, 1851, Helminthopsis, Muensteria, Neonereites, Nereites, Palaeophycus Hall, 1847, Phycosiphon, Skolithos, Syncoprulus and Yakutatia Häntzschel, 1962 (R. K. Pickerill, personal observations and collections). Notably, this assemblage includes all the ichnogenera recorded from the Wulff Land Formation with the exception of the graphoglyptids (Megagrapton and Paleodictyon). Like the assemblage from the Wulff Land Formation, it contrasts markedly with the trace fossil assemblage from Arctic Canada. Reasons for this contrast are unknown.

In a series of papers published in the 1970s, Seilacher (summarised in Frey \& Seilacher, 1980) suggested a progressive increase in flysch (deep-water) trace fossil diversity during the Palaeozoic. The three examples mentioned above are essentially coeval and contain 7-13 distinctive ichnogenera which broadly equate with the 4-8 forms documented by Seilacher, but fall short of the 20 plus forms reported by Pickerill (1980) from late Ordovician flysch of northern New Brunswick. However, it must be noted that the 12 available samples from the Wulff Land Formation constitute an extremely small sample and, furthermore, the interbedded mudstones were not sampled, although they are bioturbated (Hurst \& Surlyk, 1982). Our feeling is that more extensive collecting, especially from the mudstones, would yield an assemblage including more deposit-feeding trace fossils and would increase the overall diversity. This is perhaps further reinforced when considering that the three slope sequences discussed above contain a combined total of at least 18 distinctive ichnogenera. If the studies of Narbonne \& Packard (1983) and Narbonne \& James (1984) are included, at least 26 separate ichnogenera have been recorded from Lower Palaeozoic slope sequences to date. Future trace fossil analysis of the Wulff Land Formation (and related units) should therefore be directed to a more extensive examination of the full range of lithologies because it is only with careful and detailed analysis of such sequences that meaningful diversity models will eventually be realised.

Acknowledgements. We wish to thank John S. Peel and Martin Sønderholm for logistical support, Bob McCulloch for help with photography and Sherri Townsend for typing the manuscript. Guy Narbonne read an early draft and we are grateful for his constructive comments and John S. Peel, Martin Sønderholm and Richard Bromley provided many useful comments on the submitted manuscript. Poul-Henrik Larsen is thanked for information concerning the Wulff Land Formation. MGUH and GGU denote the collections of the Geological Museum, Copenhagen, and the Geological Survey of Greenland respectively. 


\section{References}

Benton, M. J. 1982: Trace fossils from Lower Palaeozoic ocean-floor sediments of the Southern Uplands of Scotland. Trans. R. Soc. Edinburgh, Earth Sci. 73, 67-87.

Buck, S. P. \& Bottjer, D. J. 1985: Continental slope deposits from a Late Cretaceous, tectonically active margin, southern California. J. sedim. Petrol. 55, 843-855.

Chamberlain, C. K. 1971: Morphology and ethology of trace fossils from the Ouachita Mountains, southeast Oklahoma. J. Paleont. 45, 212-246.

Chamberlain, C. K. 1977: Ordovician and Devonian trace fossils from Nevada. Bull. Nevada Bur. Mines Geol. 90, 1-24.

Cook, H. E., Field, M. E. \& Gardiner, J. V. 1982: Continental slopes. In Scholle, P. A. \& Spearing, D. R. (edit.) Sandstone depositional environments. Mem. Am. Assoc. Petrol. Geol. 31, 329-364.

Crimes, T. P. 1977: Trace fossils of an Eocene deep-sea fan, northern Spain. In Crimes, T. P. \& Harper, J. C. (edit.) Trace fossils 2. Geol. J. Spec. Issue 9, 71-90. Liverpool: Seel House Press.

Crimes, T. P. \& Harper, J. C. (edit.) 1977: Trace fossils 2. Geol. J. Spec. Issue 9, 351 pp. Liverpool: Seel House Press.

Crimes, T. P. \& Germs, G. J. B. 1982: Trace fossils from the Nama Group (Precambrian-Cambrian) of southwest Africa. J. Paleont. 56, 890-907.

Crimes, T. P. \& Anderson, M. M. 1985: Trace fossils from late Precambrian - early Cambrian strata of southeastern Newfoundland (Canada): temporal and environmental implications. J. Paleont. 59, 310-343.

Ekdale, A. A. 1977: Abyssal trace fossils in world-wide Deep Sea Drilling Project cores. In Crimes, T. P. \& Harper, J. C. (edit.) Trace fossils 2. Geol. J. Spec. Issue 9, 163-182. Liverpool: Seel House Press.

Ekdale, A. A. 1980: Graphoglyptid burrows in modern deep-sea sediment. Science 207, 304-306.

Ekdale, A. A., Bromley, R. G. \& Pemberton, S. G. 1984: Ichnology: the use of trace fossils in sedimentology and stratigraphy. Soc. Econ. Paleont. Mineral. Short Course 15, 317 pp. Tulsa: SEPM.

Fedonkin, M. A. 1977: Precambrian-Cambrian ichnocoenoses of the east European platform. In Crimes, T. P. \& Harper, J. C. (edit.) Trace fossils 2. Geol. J. Spec. Issue 9, 183-194. Liverpool: Seel House Press.

Fillion, D. \& Pickerill, R.K. 1984: Systematic ichnology of the Middle Ordovician Trenton Group, St. Lawrence Lowland, eastern Canada. Mar. Sed. \& Atl. Geol. 17, 1-41.

Fillion, D. \& Pickerill, R. K. in press: Ichnology of the Lower Ordovician Bell Island and Wabana groups, Conception Bay, eastern Newfoundland. Paleontogr. canadiana.

Frey, R. W. \& Seilacher, A. 1980: Uniformity in marine invertebrate ichnology. Lethaia 13, 183-207.

Gregory, M. R. 1969: Trace fossils from the turbidite facies of the Waitemata Group, Whangaparoa Peninsula, Auckland. Trans. R. Soc. New Zealand, Earth Sci. 7, 1-20.

Hakes, W. G. 1976: Trace fossils and depositional environment of four clastic units, Upper Pennsylvanian megacyclothems, northeast Kansas. Univ. Kansas Contrib. 63, 1-46.

Häntzschel, W. 1975: Trace fossils and problematica. In Teichert, C. (edit.) Treatise on invertebrate paleontology W. Miscellanea, supplement 1, 269 pp. Lawrence: Geol. Soc. Am. \& Kansas Univ. Press.

Hurst, J. M. \& Surlyk, F. 1982: Stratigraphy of the Silurian turbidite sequence of North Greenland. Bull. Gronlands geol. Unders. 145, 121 pp.

Kerr, J. W. 1976: Stratigraphy of central and eastern Ellesmere Island, Arctic Canada. Pt. III. Upper Ordovician (Richmondian), Silurian and Devonian. Bull. geol. Surv. Canada 260, 55 pp.

Ksiazkiewicz, M. 1977: Trace fossils in the flysch of the Polish Carparthians. Palaeontogr. pol. 36, 208 pp.

Narbonne, G. M. 1984: Trace fossils in Upper Silurian tidal flat to basin slope carbonates of Arctic Canada. J. Paleont. 58, 398-415. 
Narbonne, G. M. \& Packard, J. J. 1983: Trace fossils in Siluro-Devonian tidal flat to distal basin slope carbonates of Arctic Canada. Am. Assoc. Petrol. Geol. Ann. Meeting, Dallas 1983, Abstr. p. 136 only.

Narbonne, G. M. \& James, N. P. 1984: Ichnology of the Cambro-Ordovician Cow Head Group, western Newfoundland. Soc. Econ. Paleont. Min. Ann. Meeting, San Jose 1984, Abstr. p. 58 only.

Peel, J. S. 1982: The Lower Paleozoic of Greenland. In Embry, A. F. \& Balkwill, H. R. (edit.) Arctic geology and geophysics. Mem. Can. Soc. Petrol. Geol. 8, 309-333.

Pickerill, R. K. 1980: Phanerozoic flysch trace fossil diversity - observations based on an Ordovician flysch ichnofauna from the Aroostook-Matapedia Belt of northern New Brunswick. Can. J. Earth Sci. 17, 1259-1270.

Pickerill, R. K. 1981: Trace fossils in a Lower Palaeozoic submarine canyon sequence - the Siegas Formation of northwestern New Brunswick, Canada. Mar. Sed. \& Atl. Geol. 17, 37-58.

Pickerill, R. K., Fillion, D. \& Harland, T. L. 1984: Middle Ordovician trace fossils in carbonates of the Trenton Group between Montreal and Quebec City, St. Lawrence Lowland, eastern Canada. $J$. Paleont. 58, 416-439.

Seilacher, A. 1960: Lebensspuren als Leitfossilien. Geol. Rundsch. 49, 41-50.

Seilacher, A. 1967: Bathymetry of trace fossils. Mar. Geol. 5, 189-200.

Seilacher, A. 1977: Pattern analysis of Paleodictyon and related trace fossils. In Crimes, T. P. \& Harper, J. C. (edit.) Trace fossils 2. Geol. J. Spec. Issue 9, 289-334. Liverpool: Seel House Press.

Seilacher, A. \& Meischner, D. 1965: Fazies-Analyse im Palaozoicum des Oslo-Gebietes. Geol. Rundsch. 54, 596-619.

Sønderholm, M., Harland, T. L. Due, P-H., Jørgensen, L. N. \& Peel, J. S. 1987: Lithostratigraphy and depositional history of Silurian platform carbonates between Petermann Gletscher and J. P. Koch Fjord, North Greenland. Rapp. Grønlands geol. Unders. 133, 27-40.

Squires, R. L. \& Advocate, D. M. 1984: Meniscate burrows from Miocene lacustrine-fluvial deposits, Diligencia Formation, Orocopia Mountains, southern California. J. Paleont. 58, 593-597.

Stringer, P. \& Pickerill, R. K. 1980: Structure and sedimentology of the Siluro-Devonian between Edmundston and Grand Falls, New Brunswick. In Roy, D. C. \& Naylor, R. S. (edit.) The geology of northeastern Maine and neighbouring New Brunswick. New England Intercoll. Geol. Congr., 262277. Boston: Boston College Press.

Trettin, H. P. 1971: Geology of lower Paleozoic formations, Hazen Plateau and southern Grant Land Mountains, Ellesmere Island, Arctic Archipelago. Bull. geol. Surv. Canada 203, 134 pp.

Turner, B. R. \& Benton, M. J. 1983: Paleozoic trace fossils from the Kofra Basin, Libya. J. Paleont. 57, $447-460$.

\section{Note added in proof}

A recent paper by D'Alessandro \& Bromley (1987) has examined the taxonomy of meniscate trace fossils, and we agree with their reasoning to include most material formerly described as Muensteria von Sternberg, 1833 within Taenidium Heer, 1877. Accordingly, specimens described herein as Muensteria should be regarded as Taenidium; conclusions made in this paper, however, are unaffected by this change.

D'Alessandro, A. \& Bromley, R. G. 1987: Meniscate trace fossils and the Muensteria-Taenidium problem. Palaeontology 30, 743-763. 